\title{
Sasi Katang Balanga:Upaya Penangkapan Berkelanjutan Scylla serrata (Forskal,1775) Di Desa Leksula, Buru Selatan, Maluku
}

\section{(Sasi Katang Balanga: The Sustainable Catch Effort on Scylla serrata (Forskal,1775) in Leksula Village, South Buru, Maluku)}

\author{
Matheos Talakua ${ }^{1 *}$, Retno Peni Sancayaningsih ${ }^{2}$, Tri Joko ${ }^{2}$ \\ ${ }^{1}$ Fakultas Perikanan dan Ilmu Kelautan, Universitas Iqra Buru, Jl.Prof. Dr. Abd. Bassalamah, \\ Namlea-Maluku \\ ${ }^{2}$ Fakultas Biologi, Universitas Gadjah Mada, Jl. Teknika Selatan, Sekip Utara, Yogyakarta 55281 \\ *Email: thosymatheos@yahoo.co.id
}

(Article History: Received 22 Juli 2020; Revised 19 Agustus 2020; Accepted 24 Agustus 2020)

\begin{abstract}
ABSTRAK
Katang balanga (Scylla serrata) hidup pada dua kawasan mangrove di desa Leksula yaitu TeslatuTanjung Kabat dan Kamite Salehen. Pemerintah Desa Leksula menerapkan sasi katang balanga pada kawasan mangrove Teslatu-Tanjung Kabat. Sasi katang balanga adalah larangan menangkap katang balanga pada waktu tertentu dan cara untuk menghindari penangkapan katang balanga diluar waktu yang ditentukan. Penelitian ini bertujuan membandingkan populasi katang balanga di kawasan mangrove Teslatu-Tanjung Kabat dan Kamite Salehen dan mengetahui dampak sasi katang balanga bagi kehidupan katang balanga di Desa Leksula. Pengamatan katang balanga dan pencacahan individu per kelamin dilakukan menggunakan alat tangkap bubu, pada periode bulan terang dan gelap. Kelimpahan dan estimasi hasil penangkapan katang balanga dibandingkan menggunakan uji-t. Penerapan sasi katang balanga di kawasan mangrove Teslatu-Tanjung Kabat memberikan hasil tangkapan lebih baik. Namun demikian, perlu dilengkapi dengan sejumlah aturan untuk keberlanjutan populasi katang balanga.

Kata kunci: Berkelanjutan; Desa Leksula; Katang balanga; Sasi,Scylla serrata
\end{abstract}

\section{ABSTRACT}

Katang Balanga or mud crabs (Scylla serrata) live in two mangrove areas in Leksula, TeslatuTanjung Kabat and Kamite Salehen. Local authority in Leksula applies Sasi Katang Balanga to the Teslatu-Tanjung Kabat mangrove area. This research aims to compare the population of mud crabs in Teslatu-Tanjung Kabat and Kamite Salehen mangrove area and to know the impact of sasi on mud crabs population in Leksula. The observation of mud crabs and the enumeration of the sex of each individual was carried out by using guiding barriers or traps in the full and the new moon. The estimation of mud crabs capture results were compared using $t$-tests. The use of sasi in the TeslatuTanjung Kabat mangrove area shows a better catch results. However, it still needs to be equipped with regulations for the sustainability of mud crabs population.

Keywords: Sustainability; Leksula; Katang balanga; Sasi; Scylla serrata

\section{PENDAHULUAN}

Scylla serrata merupakan salah satu jenis kepiting bakau yang tersebar luas di wilayah Indonesia dengan kawasan mangrove sebagai habitat utamanya. S. serrata juga merupakan salah satu jenis makanan laut yang banyak diminati oleh masyarakat di Indonesia karena memiliki citarasa yang enak dan kandungan protein yang tinggi. Alfrianto dan Liviawaty (1992) menyatakan bahwa setiap 100 gram daging kepiting bakau segar, mengandung 13.6 gram protein, 3,8 gram lemak, 14.1 gram hidrat arang dan 68.1 gram air.

Di Indonesia, populasi kepiting S. serrata di alam mengalami penurunan yang diduga disebabkan oleh rusak dan hilangnya kawasan mangrove serta penangkapan lebih. Sadili et al. (2013) menyarankan agar kepiting $S$. serrata dikategorikan sebagai biota yang perlu dilindungi dan dimasukkan dalam daftar IUCN dengan status terancam punah. Keberlanjutan produksi alamiah $S$. serrata di alam sangat berkaitan dengan 
upaya pemeliharaan ekosistem mangrove dan pengelolaan penangkapan hewan tersebut.

Kepiting S. serrata juga merupakan jenis makanan laut yang diminati oleh masyarakat di Desa Leksula, Buru Selatan. Di desa tersebut kepiting ini dapat ditemukan pada dua kawasan mangrove yang letaknya terpisah yaitu kawasan mangrove TeslatuTanjung Kabat dan Kamite-Salehen. Masyarakat setempat menyebut kepiting $S$. serrata dengan nama katang balanga. Katang berasal dari kata ketam yang artinya kepiting, sedangkan kata balanga berarti periuk. Periuk yang dimaksudkan adalah bagian luar periuk yang berwarna hitam, untuk menunjukkan warna kepiting $S$. serrata yang hijau kehitaman.

Pemerintah Desa Leksula menerapkan kearifan lokal sasi katang balanga atau larangan menangkap kepiting $S$. serrata pada kawasan mangrove Teslatu-Tanjung Kabat. Tidak ada catatan resmi yang menjelaskan asal muasal sasi katang balanga diterapkan di desa Leksula. Menurut Novaczek et al. (2001) dari tuturan cerita masyarakat menunjukkan bahwa sasi di Maluku mulai dilaksanakan pada abad ke empat belas. Budaya sasi berkembang dari budaya matakao yaitu suatu tanda dengan bentuk dan jenis yang beranekaragam yang berisi formula magis yang mengandung kutukan bagi yang melanggarnya. Matakao ini sebagai suatu tanda untuk melindungi kepemilikan pribadi atau kelompok dari tindakan pencurian terhadap hasil kebun, hasil laut dan sebagainya.

Pemerintah Desa Leksula mempunyai pengaturan yang berbeda dalam hal waktu penangkapan katang balanga dikedua kawasan mangrove. Masyarakat dapat menangkap katang balanga dengan bebas dan kapan saja di kawasan mangrove Kamite-Salehen, sebaliknya penangkapan katang balanga di kawasan mangrove Teslatu-Tanjung Kabat hanya dapat dilakukan satu kali dalam setahun. Masyarakat dapat menangkap katang balanga jika pemerintah desa telah mencabut larangan tersebut.

Kissya (1993) menjelaskan sasi dapat diartikan sebagai larangan untuk mengambil (mengelola dan memanfaatkan) hasil (suatu sumber daya alam tertentu) selama periode tertentu (tiga bulan, enam bulan bahkan sampai lebih dari satu tahun), tergantung jenis sumberdaya. Sasi katang balanga adalah cara yang digunakan untuk menghindari terjadinya penangkapan katang balanga diluar waktu penangkapan yang ditentukan oleh pemerintah desa. Tujuannya adalah agar masyarakat dapat menangkap katang balanga dalam jumlah yang banyak pada saat pencabutan larangan atau saat panen bersama seluruh masyarakat desa.

Sasi katang balanga dianggap merupakan cara yang baik untuk menjamin keberlangsungan hidup dan penangkapan katang balanga di desa Leksula. Namun sampai saat ini belum ada data yang membuktikan anggapan atau pemikiran tersebut sebab selama ini belum ada penelitian tentang sasi katang balanga di desa Leksula. Berdasarkan latar belakang tersebut maka penelitian ini dilakukan untuk membandingkan populasi katang balangadi kawasan mangrove Teslatu-Tanjung Kabat dan Kamite-Salehen dan mengetahui dampak sasi katang balanga bagi kehidupan katang balangadi Desa Leksula.

\section{METODE PENELITIAN}

Penelitian dilakukan pada bulan Januari sampai dengan Maret 2015 di kawasan mangrove Teslatu-Tanjung Kabat dan Kamite-Salehen. Kedua lokasi penelitian berada di Desa Leksula, Kecamatan Leksula, Kabupaten Buru Selatan (Gambar 1). 


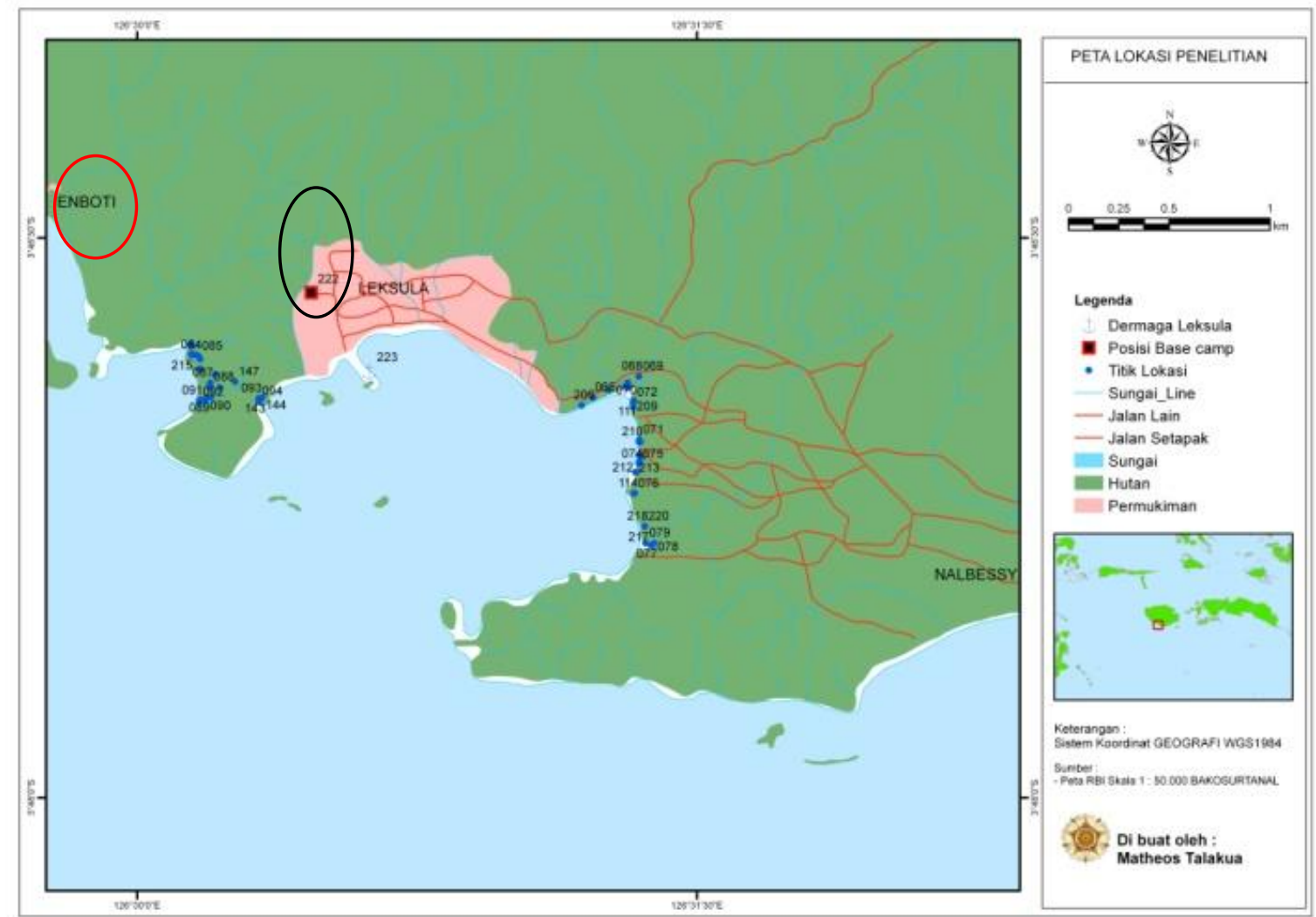

Gambar 1. Peta Lokasi Penelitian $(\bigodot$ Kamite-Salehen, $\subset$ Teslatu-Tj.Kabat)

Informasi tentang penerapansasi katang balanga didapatkan melalui wawancara dengan kepala desa dan tua-tua adat setempat dan melakukan observasi untuk mengetahui pelaksanaan sasi katang balanga di kawasan mangrove dusun Teslatu-Tanjung Kabat. Pengumpulan data kondisi habitat dikedua lokasi dilakukan dengan mengukur garis surut terjauh, ketebalan lumpur dan pengambilan sampel lumpur yang dilakukan secara acak. Sampel lumpur dianalisis untuk menentukan kelas tekstur substrat. Observasi juga dilakukan untuk mengetahui jenis bakau yang ada dikedua kawasan tersebut.Sampel lumpur dianalisis di Laboratorium Jurusan Tanah Fakultas Pertanian UGM.

Koleksi data katang balanga dikedua lokasi pengamatan dilakukan dengan menggunakan alat tangkap tradisional yang disebut bubu. Bubu terbuat dari anyaman bambu dan dilapisi dengan jaring berukuran mata 1,0 inci. Tujuan melapisi bubu dengan jaring adalah agar katang balanga berukuran kecil dapat juga tertangkap. Sepuluh buah $b u b u$ diletakkan secara acak di tiap lokasi pengamatan padasaat air laut surut, pada periode bulan terang (bulan purnama) dan bulan gelap (bulan mati). Bubu tersebut diberikan pemberat berupa batu ataupun diikat pada akar mangrove dengan tujuan agar tidak hanyut terbawa arus saat air laut pasang. Pencacahan katang balanga dilakukan sehari setelah peletakan bubu.

Data yang dikoleksi meliputi jumlah individu dan jenis kelamin. Penghitungan dilakukan terhadap kelimpahan dan estimasi penangkapan kepiting di kedua lokasi. Hasil penghitungan dikedua lokasi dibandingkan dengan melakukan pengujian statistik menggunakan uji-t. Semua data yang terkumpul diolah dan dianalisis menggunakan Microsoft Office Excel 2007.

\section{HASIL DAN PEMBAHASAN \\ Sasi katang balanga di Kawasan Mangrove Teslatu-Tanjung Kabat}

Sasi katang balanga diterapkan di kawasan mangrove Teslatu-Tanjung Kabat dengan masa berlakunya sasi selama satu tahun. Mulainya sasi katang balanga ditandai dengan pemasangan tanda sasi 
berupa pengumuman yang tertulis pada lembaran seng tipis atau papan tipis berbentuk persegi. Pengumuman tersebut bertuliskan Sasi Gereja Protestan Maluku (Gambar 2). Pengumuman tersebut dipakukan pada sepotong kayu dan ditancapkan di tanah pada beberapa tempat di sekitar kawasan mangrove tersebut, yang memungkinkan untuk dilihat dan dibaca oleh masyarakat Desa Leksula yang melintasi kawasan tersebut. Sebelum pemasangan tanda sasi, terlebih dahulu dilakukan upacara doa oleh pendeta Gereja Protestan Maluku (GPM). Pemberlakuan masa sasi selain diumumkan oleh pendeta kepada jemaat di gereja pada saat ibadah Minggu, juga diumumkan oleh pemerintah desa Leksula kepada seluruh masyarakat. Selama masa sasi, masyarakat dilarang melakukan aktivitas penangkapan katang balanga di dalam kawasan mangrove, di sungai, muara sungai dan disekitar perairan kawasan mangrove.

Pada saat masa sasi berakhir, dilakukan upacara doa di gereja sebagai tanda pencabutan sasi (buka sasi). Kemudian pendeta dan kepala desa mengumumkan kepada jemaat dan seluruh masyarakat bahwa masa sasi telah berakhir. Selanjutnya dilakukan pencabutan tanda sasi oleh pemerintah desa Leksula bersama pemilik dusun. Setelah itu masyarakat diperbolehkan melakukan penangkapan kepiting.

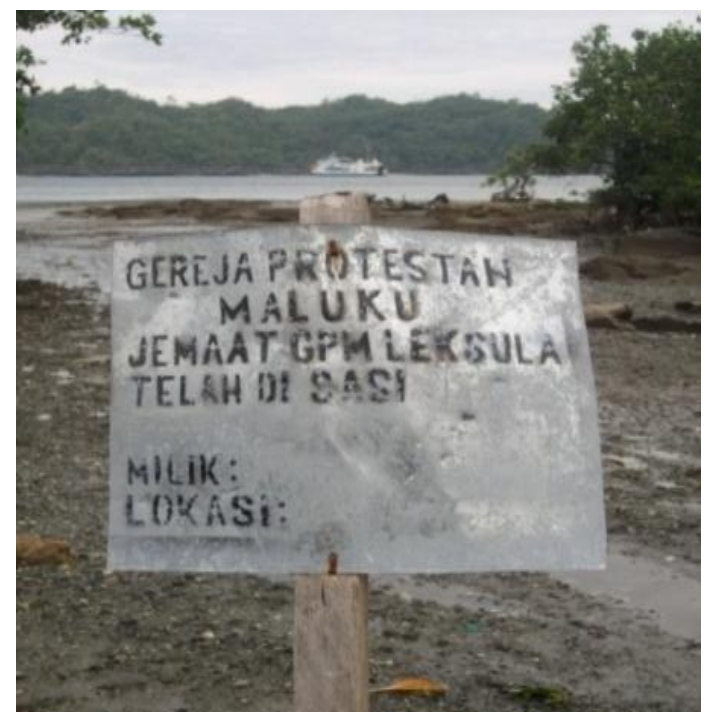

Gambar 2. Tanda Sasi

\section{Kondisi Kawasan Mangrove Teslatu- Tanjung Kabat dan Kamite-Salehen}

Kawasan mangrove Teslatu-Tanjung Kabat memiliki luas $\pm 2,5 \mathrm{Ha}$, yang terbentang di pesisir pantai Leksula di sebelah timur Desa Leksula. Panjang garis surut terjauh tegak lurus garis pantai yang dihitung dari zona depan mangrove menghadap laut berkisar antara 75-150 m. Kondisi substrat adalah lumpur berwarna hitam. Ketebalan lumpur berkisar antara 10$35 \mathrm{~cm}$. Kondisi ketebalan lumpur bervariasi mulai dari zona depan mangrove yang menghadap laut sampai ke zona belakang yang berbatasan dengan area teresterial. Hasil analisis menunjukkan bahwa substrat di kawasan Teslatu-Tanjung Kabat memiliki kelas tekstur geluh dan geluh pasiran. Pada kawasan mangrove di Teslatu-Tanjung Kabat terdapat dua aliran sungai dan anakanak sungai. Bagian utara kawasan dialiri Sungai Waefefa dengan muara sungainya yang dinamai oleh masyarakat Leksula sebagai kaki air kecil. Di bagian selatan kawasan dialiri Sungai Waesua dengan muara sungai yang disebut sebagai kaki air besar.Jenis bakau dominan yang dijumpai adalah Rhizopora sp., Brugeira sp., dan Sonneratia sp.

Luas kawasan mangrove Kamite-Selehen \pm 1,5 Ha, terbentang sepanjang pantai di sebelah barat Desa Leksula. Panjang garis surut terjauh tegak lurus garis pantai diukur dari zona depan mangrove menghadap laut berkisar antara 25-75 m. Kondisi substrat adalah pasir berlumpur dengan degradasi warna keabuan sampai warna hitam kecoklatan. Ketebalan lumpur berkisar antara 5-25 $\mathrm{cm}$ dengan kelas tekstur pasir dan pasir geluhan. Tidak dijumpai adanya aliran sungai dan anakan sungai yang bersifat permanen. Ada dua sungai temporer yang akan dialiri air pada saat musimpenghujan. Jenis bakau dominan di kawasan ini adalah Rhizopora sp., Brugeira sp., dan Sonneratia sp.

\section{Kelimpahan Katang Balanga}

Jumlah katang balanga yang tertangkap di kawasan mangrove Teslatu-Tanjung Kabat 
selama pengamatan pada periode bulan terang adalah sebanyak 57 individu, yang terdiri dari 27 individu jantan $(47,37 \%)$ dan 30 individu betina $(52,63 \%)$ (Tabel 1). Total hasil tangkapan katang balangatersebut menunjukkan rasio kelamin jantan:betina sebesar 1:1.09. Rasio kelamin ini menggambarkan proporsi yang seimbang antara katang balanga jantan dan betina dalam populasinya. Artinya tidak terdapat dominansi salah satu jenis kelamin dalam populasi katang balanga di lokasi ini.

Jumlah hasil tangkapan katang balanga pada kedua periode bulan terang dan bulan gelap menunjukkan tidak ada perbedaan yang mencolok. Jumlah katang balanga yang tertangkap di kawasan mangrove KamiteSalehen selama pengamatan dibulan Januari sampai Maret pada periode bulan terang sebanyak 2 individu (Tabel 1). Kedua individu tersebut berjenis kelamin jantan. Jumlah katang balanga di kawasan ini jauh lebih kecil dari jumlah yang ada di kawasan mangrove Teslatu-Tanjung Kabat.

Hasil tangkapan katang balanga di kawasan mangrove Teslatu-Tanjung Kabat selama pengamatan pada periode bulan gelap sebanyak 54 individu, yang terdiri dari 30 individu jantan $(55,56 \%)$ dan 24 individu betina $(44,44 \%)$ (Tabel 2). Total hasil tangkapan katang balangatersebut menunjukkan rasio kelamin jantan:betina sebesar 1:1.25. Sementara jumlah katang balanga yang tertangkap di kawasan mangrove Kamite-Salehen selama pengamatan pada periode bulan gelap sebanyak 3 individu dan ketiganya berjenis kelamin betina (Tabel 2).

Tabel 1. Jumlah individu dan rasio kelamin katang balanga jantan dan betina yang tertangkap pada bulan Januari sampai Maret pada periode terang di kawasan mangrove TeslatuTanjung Kabat dan Kamite-Salehen

\begin{tabular}{cccccc}
\hline \multirow{2}{*}{ Kawasan } & Bulan & \multicolumn{3}{c}{ Individu Katang Balanga } & $\begin{array}{c}\text { Rasio } \\
\text { Kelamin }\end{array}$ \\
\cline { 3 - 6 } & & Jantan & Betina & Jumlah & \\
\hline \multirow{2}{*}{ Teslatu- } & Januari & 13 & 12 & 25 & \\
Tanjung & Pebruari & 9 & 11 & 20 & \\
Kabat & Maret & 5 & 7 & 12 & \\
& Jumlah & 27 & 30 & 57 & $1: 0,9$ \\
\hline \multirow{2}{*}{ Kamite- } & Januari & 2 & 0 & 2 & \\
Salehen & Pebruari & 0 & 0 & 0 & \\
& Maret & 0 & 0 & 0 & - \\
\hline
\end{tabular}

Ket.: Data diatas telah disampaikan dalam seminar internasional ICTA pada Oktober 2016

Tabel 2. Jumlah individu dan rasio katang balanga jantan dan betina yang tertangkap pada bulan Januari sampai Maret pada periode bulan gelap di kawasan mangrove TeslatuTanjung Kabat dan Kamite-Salehen

\begin{tabular}{cccccc}
\hline \multirow{2}{*}{ Kawasan } & Bulan & \multicolumn{3}{c}{ Individu Katang Balanga } & Rasio \\
& & Kelamin \\
\cline { 3 - 6 } & Januari & 10 & 11 & 21 & \\
\hline \multirow{2}{*}{ Teslatu- } & Pebruari & 12 & 6 & 18 & \\
Tanjung & Maret & 8 & 7 & 15 & \\
Kabat & Jumlah & 30 & 24 & 54 & $1: 1.25$ \\
& Januari & 0 & 1 & 1 & \\
Kamite- & Pebruari & 0 & 2 & 2 & \\
Salehen & Maret & 0 & 0 & 0 & - \\
& Jumlah & 0 & 3 & 3 & - \\
\hline
\end{tabular}

Ket.: Data diatas telah disampaikan dalam seminar internasional ICTA pada Oktober 2016 
Jumlah tangkapan katang balanga pada kedua periode bulan terang dan bulan gelap di kawasan magroveTeslatu-Tanjung Kabat menunjukkan tidak ada perbedaan yang mencolok. Namun hasil tangkapan katang balanga di lokasi ini per bulan pengamatan cenderung mengalami penurunan. Aktivitas pembukaan lahan mangrove di kawasan tersebut yang dilakukan sejak awal Februari, yang diperuntukkan bagi pembangunan sarana stasiun pengisian bahan bakar minyak, dapat mempengaruhi hasil tangkapan dalam penelitian ini. Aktivitas tersebut dapat menyebabkan kerusakan habitat bagi banyak spesies penghuni kawasan mangrove, seperti katang balanga. Menurut Indrawan et al. (2012) bahwa salah satu ancaman utama pada keanekaragaman hayati akibat kegiatan manusia adalah kerusakan dan degradasi habitat.

Hutan mangrove di pesisir pantai yang mengalami degradasi dan destruksi secara luas akan menyebabkan hilangnya fauna dan flora jika tidak ada tindakan yang tepat untuk melakukan konservasi dan atau rehabilitasi (Duke et al. 2007). Supriharyono (2007) menjelaskan bahwa hilangnya hutan mangrove akan menyebabkan turunnya produktivitas ekosistem wilayah pesisir sebab ekosistem wilayah pesisir mempunyai potensi sumberdaya alam hayati dan nonhayati yang sangat tinggi.

Total hasil tangkapan katang balanga di kawasan mangrove Teslatu-Tanjung Kabatberjumlah 111 individu. Bila dibandingkan dengan luasan kawasan mangrove tersebut, jumlah tangkapan ini dapat dikatakan sedikit. Hal ini dipengaruhi oleh aktivitas penangkapan yang telah dilakukan warga pada saat bukasasi dibulan Desember 2014. Populasi katang balanga yang teramati selama penelitian ini adalah individu katang balanga yang tidak tertangkap pada saat bukasasi. Pada saat buka sasi, masyarakat berbondong-bondong melakukan penangkapan sebanyak mungkin katang balanga. Dalam penangkapan tersebut ada warga yang menggunakan racun alami yang ditebarkan di aliran dan muara sungai (Komunikasi personal dengan Bpk.Oni Lesnussa). Dengan demikian populasi katang balanga yang teramati selama penelitian ini adalah katang balanga yang tidak terpapar racun alami.

Total jumlah tangkapan katang balanga di kawasan mangrove Kamite-Salehen sebanyak 5 individu. Jumlah yang sangat minim ini dipengaruhi oleh aktivitas penangkapan dan kondisi habitat. Tidak adanya penerapan sasi di lokasi ini memungkinkan masyarakat melakukan penangkapan sesering mungkin yang berakibat pada menurunnya populasi katang balanga. Dapat dikatakan bahwa penurunan populasi katang balanga di kawasan iniadalah karena telah terjadi mortalitas penangkapan dan tidak adanya rekrutmen individu baru kedalam populasi katang balanga.

Faktor lain yang diduga turut berpengaruh terhadap kelimpahan katang balanga di kawasan iniadalah tidak adanya aliran dan muara sungai permanen. Aliran air tawar dari daratan hanya terjadi secara musiman yaitu saat musim penghujan. Secara ekologis, sungai dan muara sungai sangat penting karena merupakan jalur masuk bagi katang balanga juvenil yang bermigrasi dari laut ke kawasan mangrove untuk selanjutnya berkembang menjadi individu dewasa. Ketiadaan aliran dan muara sungai akan membatasi rekrutmen kepiting baru ke dalam populasi dan juga mempengaruhi pembentukan substrat.

Hasil analisis substrat menunjukkan di kawasan mangrove Kamite-Salehen didominasi tekstur pasir dan pasir geluhan. Sementara kondisi substrat yang sesuai bagi katang balanga adalah geluh pasiran dan geluh, untuk memudahkan membenamkan tubuh dalam liang yang dibuatnya pada saat air laut surut. Suryani (2006) menjelaskan bahwa kepiting bakau biasanya lebih menyukai tempat yang agak berlumpur dan berlubang-lubang di daerah hutan mangrove. 
Dampak Penerapan Sasi dan Revitalisasi Aturan Sasi katang balanga

Estimasi hasil tangkapan katang balanga dengan usaha tangkapan yang dilakukan (= trip) di kedua lokasi dapat dibandingkan. Estimasi hasil tangkapan katang balanga di kawasan mangrove Teslatu-Tanjung Kabat 1.85 ekor/trip, sedangkan di kawasan mangrove Kamite-Salehen 0.08 ekor/trip (Tabel 3). Hasil uji statistik dengan menggunakan uji-t didapat $t_{h i t}=1,91$ dan $\mathrm{t}_{\text {tabel }}=2,00$ dengan $\mathrm{n}=59$ dan $\alpha=0,05$ sehingga diperoleh $t_{\text {hit }}<t_{\text {tabel }}$, artinya estimasi hasil tangkapan katang balanga di kedua kawasan berbeda sangat nyata pada taraf kepercayaan 95\% $(\alpha=0,05)$. Hasil hitung statistik ini menunjukkan bahwa penerapan sasi di kawasan mangrove Teslatu-Tanjung Kabat memberikan hasil tangkapan katang balanga yang lebih baik dibandingkan dengan kawasan mangrove Kamite-Salehen.

Tabel 3. Estimasi Hasil Tangkapan Katang Balanga dengan alat tangkap bubu

\begin{tabular}{cccc}
\hline Kawasan & $\begin{array}{c}\text { Hasil tangkapan } \\
(\text { Catch })\end{array}$ & Usaha (f)* & $\begin{array}{c}\text { Catch/Usaha } \\
(\mathrm{C} / \mathrm{f})\end{array}$ \\
\hline Teslatu-Tanjung Kabat & 111 & 60 & 1,85 \\
Kamite-Salehen & 5 & 60 & 0,08
\end{tabular}

Ket.: Usaha dihitung dari jumlah alat tangkap bubu sebanyak 10 buah tiap lokasi, 2 kali pengamatan diperiode terang dan gelap selama waktu 3 bulan Data diatas telah disampaikan dalam seminar internasional ICTA pada Oktober 2016

Penerapan sasi katang balanga di kawasan mangroveTeslatu-Tanjung Kabat perlu dilengkapi dengan aturan yang memadai, sanksi dan sosial kelembagaan dengan tujuan untuk melindungi, melestarikan dan memanfaatkan sumberdaya kawasan mangrove secara berkelanjutan. Tuhumuri (2004) menjelaskan bahwa sasi dapat dikatakan sebagai usaha yang mengarah kepada konservasi, namun aturanaturan dalam sasi itu sendiri belum memadai untuk konservasi sebenarnya. Aturan sasi harus dibuat secara jelas untuk memenuhi prinsip konservasi yaitu perlindungan, pelestarian dan pemanfaatan suatu sumberdaya secara berkelanjutan.

Widodo dan Suadi (2008) menyatakan bahwa usaha penangkapan perikanan saat kini membutuhkan manajemen pengelolaan perikanan dengan mempertimbangkan aspek biologi, ekologi dan lingkungan, sosial, budaya dan kelembagaan, dan aspek ekonomi. Hal ini dilakukan untuk menjamin ketersediaan populasi ikan dari waktu ke waktu dan menghindari tangkap lebih. Supriharyono (2007) menjelaskan bahwa aktivitas manusia yang tidak terkendali telah menyebabkan perusakan lingkungan sumberdaya alam, baik di daratan (hutan) maupun di lautan. Aktivitas yang tidak terkendali tersebut, bila tidak dikelola dengan baik maka potensi sumberdaya alam termasuk genetic resources di darat dan di lautan akan mengalami kepunahan. Oleh karena itu dibutuhkan kawasan konservasi untuk menghindari terjadinya kepunahan tersebut.

Penerapan sasikatang balanga pada kawasan mangrove Teslatu-Tanjung Kabat dapat dikatakan sebagai konservasi tradisional. Mengacu pada prinsip biologi konservasi yang berfokus pada nilai perlindungan, pelestarian dan pemanfaatan sumberdaya hayati secara berkelanjutan maka penerapan sasikatang balanga di desa Leksula perlu diperlengkapi dengan aturan memenuhi prinsip biologi konservasi. Aturan sasi yang dibuat haruslah berisi waktu penangkapan, perlindungan habitat, penggunaan alat tangkap ramah lingkungan atau non-destruktif, jumlah dan ukuran katang yang layak ditangkap.

Upaya perlindungan dan pemanfaatan kepiting bakau di alam juga dilakukan oleh pemerintah Republik Indonesia melalui Menteri Kelautan dan Perikanan Republik 
Indonesia dengan mengeluarkan Peraturan Menteri (Permen) Nomor 1/PERMEN$\mathrm{KP} / 2015$ tentang penangkapan Lobster (Panulirus spp.), Kepiting (Scylla spp.), dan Rajungan (Portunus spp.). Khusus untuk kepiting bakau, peraturan menteri tersebut berisi larangan menangkap kepiting bakau dengan ukuran lebar karapas $<15 \mathrm{~cm}(<150$ $\mathrm{mm})$.

Hal ini adalah tepat karena secara biologi, kepiting pada ukuran tersebut berada dalam fase dewasa awal dan belum matang kelamin. Jika larangan ini ditaati, kepiting dengan ukuran tersebut dapat berkembang menjadi kepiting dewasa dan matang kelamin, selanjutnya akan menghasilkan individu baru untuk meningkatkan populasinya.

Kepiting bakau dengan ukuran tersebut memiliki berat badan yang kecil dan tidak memadai untuk dikonsumsi. Penangkapan kepiting bakau dengan ukuran lebar karapas $>15 \mathrm{~cm}(>150 \mathrm{~mm}$ ) adalah tepat karena kepiting bakau dengan ukuran tersebut telah memasuki fase dewasa dan matang kelamin serta diduga telah menghasilkan individu baru. Kepiting bakau dengan ukuran $>15$ $\mathrm{cm}(>150 \mathrm{~mm})$ telah memiliki berat badan yang memadai untuk dikonsumsi serta memiliki nilai ekonomis tinggi di pasaran.

Kepiting bakau dengan ukuran yang memadai untuk ditangkap haruslah didasarkan pada siklus hidup dan usia harapan hidupnya. Berkaitan dengan haltersebut maka waktu penerapan sasi katang balanga haruslah diperpanjang menjadi 2 tahun. Phelan dan Grubert (2007) menjelaskan bahwa kepiting $S$. serrata akan mencapai ukuran lebar karapas $100 \mathrm{~mm}$ dalam waktu kurang lebih satu tahun dan akan mencapai kematangan kelamin (sexual maturity) dalam waktu kurang lebih 2 tahun.

Bila mengacu pada pendapat tersebut maka penerapan sasi katang balanga selama setahun hanya menjamin keberlangsungan hidup kepiting fase juvenil dan fase dewasa awal, dan belum menjamin keberlangsungan hidup kepiting fase dewasa dan matang kelamin. Jika induk kepiting betina mencapai puncak kematangan gonad pertama dibulan Januari, Februari dan Maret maka pada bulan yang sama pada tahun berikutnya, anak kepiting dari induk betina tersebut baru mencapai fase dewasa awal, dan baru pada tahun berikutnya kepiting tersebut mencapai fase matang kelamin. Hamasaki et al. (2011) menjelaskan bahwa ukuran kematangan seksual dan komposisi ukuran tubuh kepiting bakau merupakan dasar dalam regulasi perikanan untuk penangkapan minimum dan untuk mencegah degradasi habitat mangrove secara serius.

Aturan pemerintah tentang larangan penangkapan kepiting bakau betina yang bertelur (matang gonad) adalah tepat karena secara biologi akan memberikan kesempatan kepiting tersebut menghasilkan individu baru untuk siklus rekrutmen kedalam populasi kepiting. Sebaliknya, bila penangkapan kepiting bakau betina matang gonad berlangsung secara intensif maka terjadi pemutusan siklus rekrutmen individu baru. Akibatnya populasi kepiting bakau di alam dapat mengalami penurunan bahkan terancam punah. Aturan pemerintah ini diharapkan dapat dimasukkan dalam aturan sasi katang balanga pada kawasan mangrove Teslatu-Tanjung Kabat sehingga menjamin keberlanjutan populasi katang balanga dan berimplikasi menjamin penangkapan kepiting tersebut secara berkelanjutan.

\section{KESIMPULAN}

Penerapan sasi katang balanga di kawasan mangrove Teslatu-Tanjung Kabat memberikan hasil tangkapan katang balanga yang lebih baik dibandingkan dengan kawasan mangrove Kamite-Salehen yang tidak ada penerapan sasikatang balanga. Penerapan sasi katang balanga di kawasan mangrove di Desa Leksula akan berimplikasi terhadap penangkapan katang balanga (S. serrata) secara berkelanjutan bila aturan sasi yang dibuat mengatur perlindungan habitat, waktu penangkapan, penggunaan alat tangkap ramah lingkungan, jumlah dan ukuran yang layak ditangkap.

\section{UCAPAN TERIMA KASIH}

Diktendik Dikti Kementerian Pendidikan Nasional Republik Indonesia sebagai pemberi Beasiswa Program Pra S2/S2 3T 
tahun 2012/2013 dan Dr. Suadi,M.Sc. (Dosen Jurusan Perikanan dan Kelautan Fakultas Pertanian,UGM).

\section{DAFTAR PUSTAKA}

Alfrianto E, Liviawaty E (1992) Pemeliharaan kepiting, Kanisius, Jakarta,hal 74.

Duke NC, Meynecke JO, Dittmann S (2007) A World without mangrove? Science 317: 41-42.

Hamasaki K, Matsui N, Nogami M (2011) Size at sexual maturity and body size composition of mud Crabs Scylla spp. Cought in Don Sak, Bandon Bay, Gulf of Thailand, Fish Science 77: 49-57.

Indrawan M, Primack RB, Supriatna J (2012) Biologi konservasi (edisi revisi), Yayasan Pustaka Obor Indonesia, Jakarta, hal 87-183.

Kissya E (1993) Sasi aman haruUkui,Yayasan Sejati, Jakarta, hal 5-7.

Novaczek I, Harekes IHT, Sopacua J, Tatuhey MDD (2001) An institutional analysis of sasi laut in Maluku, Indonesia, ICLARM Technical Report 59, Penang, Malaysia.

Peraturan Menteri Kelautan dan Perikanan Republik Indonesia Nomor 1/PERMENKP/2015 Tentang Penangkapan Lobster (Panulirus spp.), Kepiting (Scylla spp.), dan Rajungan (Portunus spp.)

Phelan M,Grubert M (2007) The life cycle of the mud crab, Northern Territory Government, Fishnote No 11.

Sadili D, Sarmintohadi, Mustika C (2013) Biota perairan terancam punah di Indonesia, prioritas perlindungan, DKK \& JI Ditjen KP3K Kementerian Kelautan dan Perikanan/LIPI, Jakarta, hal 176-177.

Supriharyono (2007) Konservasi ekosistem sumberdaya hayati, di Wilayah Pesisir dan Laut Tropis,Pustaka Pelajar, Yogyakarta, hal1-11.

Suryani (2006) Ekologi kepiting bakau (Scylla serrata Forskal) dalam ekosistem mangrove di Pulau Enggano Provinsi Bengkulu.Tesis. Program Studi Manajemen Sumber Daya Laut Pascasarjana Universitas Diponegoro. Semarang.

Tuhumuri, E. 2004. Pengembangan sistem sasi sebagai upaya konservasi ikan lompa (Thryssa baelama Forsskal) Di Desa Haruku, Maluku Tengah.Tesis. Departemen Biologi, ITB. Bandung.

Widodo J, Suadi (2008) Pengelolaan sumberdaya perikanan laut. Gadjah Mada University Press, Yogyakarta,hal 74-77. 